UDC: 81'243; 81'27

\title{
- LINGUISTIC AUTOBIOGRAPHIES OR MAKING SENSE OF ONE'S LANGUAGE LEARNING EXPERIENCE. CASE STUDY
}

\author{
ELENA BONTA, RALUCA GALIȚA ${ }^{1}$ \\ „Vasile Alecsandri" University of Bacău, \\ Faculty of Letters \\ Bacău, Romania
}

Cilj ovog rada je da istraži jedan vid ličnog/autobiografskog narativa kao posebnog oblika pripovedanja, koji se smatra kako predmetom tako i načinom istraživanja u obrazovanju. Rad polazi od ideje da jezičke autobiografije predstavljaju važan izvor informacija o iskustvu kroz koje prolaze učenici drugog/stranog jezika, ali i o načinu na koji taj jezik razumeju. Ova analiza se zasniva na jednom prikazanom slučaju i pokušava da odredi razloge učenja, usvajanja i (ponovnog) korišćenja jezika u svakodnevnim životnim situacijama, ili pak odustajanja od takvog cilja. Nakon analize predstavljeni su mogući uticaji koje bi vežbanje i učenje jezičke autobiografije moglo da ima u nastavi jezika i obrazovanju učenika uopšte.

Ključne reči: priča/lični narativ, jezička autobiografija, sadržaj, kontekst, oblik.

\section{PRELIMINARIES}

Generally speaking, narratives represent modes of communication and offer individuals the possibility of understanding the outside world, as well as the inside one. Among them, an important place is held by personal narratives, considered to be meaning -making tools during individuals' experience (Polkinghorne 1988). They are, according to Pavlenko (2007:164), known under different names: linguistic autobiographies, language learning protocols, language learning accounts, language journals or diaries. They are given a special attention especially in applied linguistics (and not only), due to the fact that they are one possibility of "getting" inside individuals" own world and coming into contact with his/her linguistic experiences and processes of becoming bior multilingual under specific socio-linguistic circumstances. It is a fact that individuals find meanings in their own experience and express these meanings in words; in fact, they "use the act of narration to impose meaning on experience" (Pavlenko 2007: 167).

1 Kontakt podaci (Email): elenabonta@yahoo.com; ralucagalita@yahoo.com 
Personal narratives/ autobiographies, along with (non)participant observation, in-depth interviews, reflective journals, document analysis, have become powerful research tools in qualitative research (whose concrete manifestation is represented by qualitative data analysis).

The qualitative research brings into focus of analysis both verbal and nonverbal behaviour with the main goal of finding answers to "why" and "how" of human behaviour. It also conveys experiences that are meaningful and salient to participants to the study, accompanied by participants' feelings, dispositions, interests, value systems, motivations and attitudes and treats them as analytical objectives. Study participants' actions, the situation and the time when they took place are brought together, and the relationship between them is explored, as participants interpret situations and attach different meanings to their behaviour in different contexts. Generally, the qualitative research gets data from video or audio recordings, individual or group written material and field notes, in its attempt of exploring a phenomenon from daily existence. It uses open-ended questions in order to gather data, which then constitute the basis/ "ground" for theory. In contrast to the quantitative research, based on statistics and objective inquiry and operating with surveys and questionnaires, the qualitative research gives participants to the study the possibility of spontaneous expression or adaptability to interaction (in the case of face-to-face interviews) and of complex /elaborate narratives (in autobiographies, journals, diaries). Hence the flexible character of this type of research (adaptation/flexibility, from the part of the participant and flexible style from the part of the researcher in what concerns the instruments he uses for investigation and data processing).

In applied linguistics, both research approaches can be used, as they are not mutually exclusive; on the contrary, although they approach reality in their specific ways, with specific instruments, they complement and support each other. More than this, used together, they increase strengths while eliminating weaknesses of the research (Dörnyei 2007: 45). Thus, the so-called "mixed methods research" (Dörnyei 2007:42), that is, a combination of qualitative and quantitative methodologies, techniques, methods, concepts, has gained ground over the past 15 years. Strauss and Corbin advocate an interplay between the two (Dörnyei 2007: 43) as this strategy ensures the incorporation of "the strengths of both methodologies" (Johnson and Onwuegbuzie 2004: 23), offering a "multi-level analysis of complex issues" (Dörnyei 2007: 45), improving validity of research and offering final results that address to a larger audience than those offered by either of the approaches, operating separately.

Our paper uses the qualitative research only, out of two reasons: on the one hand, we have considered linguistic autobiography as a type of narrative having a direct, flexible and informal style of writing, in which we can feel the participants' deep involvement in their own actions, requiring us to "discover" the innermost meanings they construct through words and behaviour. On the other hand, the paper is meant to offer a possible model of linguistic autobiography data analysis and does not focus on results.

\section{FRAMEWORK OF ANALYSIS}

Analysing the problem of personal narratives in the context of applied linguistics, Pavlenko (2007) considers that little has been done in the field of personal narrative 
analysis and, as a consequence, data collecting is not always followed by a proper analysis of outcomes. Starting from this, she offers a critical review of the analytical framework applied to second language users' personal narrative. She considers that "autobiographic narratives are cultural, institutional, and social productions..." (Pavlenko 2007:173) and must be analysed at a macro-level (the political, economic, cultural circumstances) and at a micro-level (content, context and form), in a very close relationship to one another, as they have a decisive role in explaining how individuals make sense of their experiences in everyday life and contexts.

Bruner (1990) shares the same opinion. For him, narratives represent the basic form through which individuals give an account of the way in which they make sense of their experiences, of the world around. He examines the account as narrative, starting from the analysis made by Burnett in this direction and from the conception according to which "accounting, in its broadest sense, refers to all attempts to understand and explain experience" (Burnett 1991: 122).

The paper draws especially on Pavlenko's theoretical framework, which she modestly named "recommendations for systematic analysis" (2007:163) but which proves, in fact, to be a new approach that "encourages the analyst to consider not only what was said or written but also what was omitted and why" (2007:172). The paper analyses one linguistic autobiography from the perspective of content, contextand form, considering these elements as being in a close connection to one another. It even tries to interpret the "said" and the "unsaid" in an attempt of identifying how both the linguistic and social self are constructed through awareness, knowledge, attitude and skills acquired in everyday life experience.

\section{AIMS OF THE STUDY}

The specific aims of the study may be summarized as: 1) trying to explain how contexts (of different sorts) generate possibilities for language learning encounters and varied experiences; 2 ) establishing the types of specific goals that lead to acquisition/ learning of languages, as well as to their use and re-use in different settings; 3) identifying outcomes of the very complex and (sometimes) painstaking process of learning languages in a multicultural setting; 4) identifying implications for teaching languages and for student education, in general; 5) offering a possible model of written autobiographical data analysis.

\section{METHOD}

\subsection{PARTICIPANTS AND PROCEDURE}

A number of 30 linguistic autobiographies (written by teachers of English, students majoring and minoring in English, writers, journalists and artists) were collected during a period of six months. ${ }^{2}$ Out of this number, we have chosen one of them for analysis, at

2 Research for this paper was made possible by the international project "Kaléidoscope: langues en couleurs" (KALECO), 143452-2008-IT-KA2-KA2MP, financed by The European Commission. 
random. ${ }^{3}$ It belongs to a teacher of English and German, aged 31. A Romanian by birth, she faced the difficulties of studying German, she was taught English and French and ended up an English teacher (this explains why the linguistic autobiography is written in English; she intends to use it as a model for her students in class). For convenience, we shall simply name her R (from "respondent") in the course of our analysis.

\subsection{MODE OF INQUIRY4}

The paper combines various approaches: theoretical (presentation of the theoretical background of the problem and of the conceptual framework), interpretive (analysis of the outcomes and interpretation of data followed by conclusions regarding the ways in which the subject made sense of her language learning experience) and critical (critical appraisal of the outcomes).

\subsection{OUTCOMES AND DISCUSSION}

The information that we have gathered from the linguistic autobiography centers round what Pavlenko (2007:165) calls subject reality (with reference to the manner in which things/events were experienced by our subject), life reality (things and events as they were) and text reality (the ways in which the subject narrates experience), aspects that represent the point at which the macro-level and the micro-level of analysis meet each other.

R's accounts of events in life (which contributed to her shaping identity as a multicultural individual) become "recollections of events organized into narrative form" (Burnett 1991:122), the purpose of which is not only to describe but also to explain (causes, effects, motivations) with the aim of understanding.

The "performance" (Riessman 1993: 9) of the linguistic autobiography begins with social, affective and psychological dimensions, marking, at the same time, the beginning of the stream of consciousness whose materializations include thoughts, feelings, intentions and memories (Burnett 1991:124).

The first things to be mentioned are those connected with the details circumscribing both explicitly and implicitly the local context of existence (R mentions that she was born in a city whose multicultural aspects were given by the ethnic groups residing in it). This creates, from the very beginning, certain expectations in the reader: to have access to information about the mentioned ethnic groups, to R's encounters with members of the respective ethnic group(s), her acquisitions of linguistic elements from their discourses and the way in which they were/have been able to "act" upon her daily existence and identity.

Mentioning that the linguistic context in which she was born was that in which all the members of the family spoke "standard" Romanian, R hints at sameness within the

3 We have opted for this technique as we started from the assumption that all linguistic autobiographies we collected could offer the same elements for analysis, with variations in number of experiences, acquired languages, amount of details and manner of presenting things and events.

4 Considering that "A mode of inquiry is a particular stance an analyst takes in order to accomplish an integral part of a research project", Carbaugh (2007:170) mentions the five distinctive modes: theoretical, descriptive, interpretive, comparative and critical. 
framework of the immediate social and linguistic context, the one with which most of us are accustomed. Difference is recognized once R has the first "confrontation" with a bilingual context (with people belonging to the Csango ethnic group - a Hungarian ethnic group of Roman (atholics living in a neighbouring village). This first encounter is described in terms of social, cognitive and psychological dimensions of the learning process. Under the circumstances, $\mathrm{R}$ does not learn a second language (as expected by the reader). She learns (through discovery, while facing the contextual elements) things about the neighbouring reality: there are people speaking a different language "so close" to her (although she had no idea about their existence) and they cannot understand what she says, the same, as she cannot understand them. The encounter shocks her; she feels "amazed" and "frustrated". The terms, based on adjectives with opposite values, suggest the complexity of the feeling in front of diversity, in a sincere and open recollection. Thus, $R$ acquires knowledge through practice, becomes aware of diversity and difference while experiencing things and contradictory feelings. Yet, she also recollects: "It was only later that I understood what 'multiculturality' really meant." It is, in fact, a hint at the natural way of dealing with things: perception is followed by cognition and this does not necessarily happen at the same time.

It is during the second grade in school when $\mathrm{R}$ begins her proper linguistic development in a foreign language. Events in the linguistic autobiography are now arranged chronologically. Thus, German is the first language she begins to study while being a child, out of extrinsic motivation (her father was a teacher of German and he tried "to pass" his love for German on to his daughters). Together with this, perception on the new language is revealed: at that moment, German was considered too difficult and so, R stopped learning it. The study of the other two languages, English and French (during secondary school and college) also had extrinsic motivations at their basis: the educational system was offering the options, as part of the first and second compulsory foreign languages programme in school curricula.

Description and explanation become two favourite ways of dealing with things and events. Social, cultural and political contexts mingle with individual experience in R's life. She mentions the 1989 revolution in the country, which brought about a change in mentality, in education, as well as in the openness towards other countries and cultures along with multiple possibilities of travelling and studying abroad. The motivational development is also to be noticed: "father as a model" is no longer enough. The model of a young fellow beginning her studies abroad gets priority ("I started fantasizing about studying abroad"- mentions R). Extrinsic motivation gives room to the intrinsic one ("I asked my father to teach me German, so that I could pass the entrance examination at the Faculty of Letters") along with a sudden realization of a change in perspectives ("It was the first time in my life when I realized that studying abroad was not just a fantasy, but a dream that could come true."). R forgets about previous difficulties in studying German and she embarks on a difficult "voyage" of acquiring and learning it. We can easily notice how she makes sense of the advantages the study of a foreign language might trigger and how this becomes a springboard for her next "steps" in her daily existence.

She also perceives the revolution as a turning point in her development as a multilingual person. The major event in the country brought, among other things, 
the possibility, for her, to study English at school, being taught by foreign teachers (with a direct result in the quality of teaching and improvement in knowledge). This marks another step in R's developing awareness about language learning (the foreign language professors were strict with Romanian students as they wanted to "push us up over the edge, over the barriers between knowing a certain foreign language and really thinking and writing in that language as if it were the mother tongue") and about the changes in the educational system, with major influence on her development as a person.

As she decided to attend the courses offered by the foreign languages department at university, she acknowledged that difficulties in learning German were both linguistic ("I remember how hard it was for me to assimilate in such a short time the German grammar and lexical structures suitable for a standard level.") and nonlinguistic ("professors at university were very strict" - a thing that put more pressure on her studies). Determination helped her go beyond limits and hard work was "rewarded": she got a scholarship in Germany. In the new context, $\mathrm{R}$ felt, at first, as "a small fish in the ocean" and she could not "find the place in the German society". She could not adapt to people around her (who were all speaking a different language) and "the transition from the Romanian society to a cosmopolitan city was difficult not only from a linguistic point of view, but also from a social and cultural perspective". Expression of feelings is combined with awareness about the multi-faceted aspects involved in the act of learning and living abroad, as well as about her lack of necessary abilities in a multicultural environment. Therefore, the linguistic choices she makes in order to express all these belong to the semantic field of "Ioss" or "inadaptability".

The reactions in front of the new reality are still alive in her memory: "my mouth would not open and I would blush, panic and stammer". Ambivalent reactions characterize her behaviour: "I always felt the need of using a dictionary although I understood what they were saying". The account may be interpreted as awareness of the need to be like the others and successfully respond to requirements, showing perfect adaptation to the new context. Two new objectives in learning and self-training are also explicitly introduced. $R$ wants to handle the structures of the new required language: German (the language used by all foreign students - natives or non-natives, coming from 50 different countries and with whom she shared the same linguistic context). More than this, she wants to practise French (as she wanted to better understand her French friend, living in the same context and displaying little knowledge of English and no knowledge of German).

What is important, is the fact that it was not only $\mathrm{R}$ who strived hard to overcome linguistic and socio-cultural differences, but all the foreign students around her did the same thing, with the same objective ("we were all eager to get on well with each other"), and R was conscious of those efforts and mentioned them in detail ("through desperate gestures and with the help of dictionaries we managed to communicate"). On the one hand, they jointly, through common efforts, tried to reduce differences while on the other, they "brought" into interaction elements of their national identity (enhancing pride for being different and having something to counter-part others' "exhibits"): they cooked traditional meals, taught the others how to dance their national specific dances, offered national drinks to their new friends. Thus, that period was rich for her 
in experiences: $R$ discovered the taste of "empanadas, chimichurri, asado, dulce de leche or caipirinha cocktails" and along with these, she discovered similar grammatical and lexical constructions between Romanian, Spanish and Portuguese. She also learnt that "Paris did not mean only Moulin Rouge, Tour Eiffel or Champs Elisée, but also Matisse, Monet, Gaugain, Tournier, Makine" and also drew differences between significant revolutions in Romania (1989) and France (1968). It was through these experiences that $\mathrm{R}$ got real understanding of distinctive identities, as a result of various activities and daily experiences and, at the same time, she shaped her own identity among the members of the group as individuals and among them as representatives of various and different other nations from Europe and America. That was also the period in which her identity as a "plurilingual student" was shaped and confirmed in interaction (she "passed from German to English, to French, even to Swedish without great difficulty... and deciphered unknowingly various cultural codes").

The linguistic experience in Germany seemed to have marked her life and, at the same time, the choice of her career as a teacher of foreign languages. Why a teacher of English and not of German? Because that was the only job position she could apply for when she graduated. External constraints played a decisive role in R's employment. German has remained the second choice and she teaches it, but only in private tuition.

\section{IMPLICATIONS FOR TEACHING A FOREIGN LANGUAGE AND FOR STUDENT EDUCATION}

Why and how can linguistic autobiographies represent a tool for teaching a foreign language and for student education, in general? The answer is to be found in the multitude of outcomes revealed by our case study itself and which might constitute goals in teaching and educating students. Awareness, knowledge, attitudes and skills are among the outcomes of language learning experience for $R$ and she shares them, as a particular individual living among the others:

a) awareness:

- $\quad$ regarding efforts of learning a foreign language: ("the efforts paid off and I found myself in the position of getting a scholarship.");

- $\quad$ regarding (cultural) diversity: people coming from different countries, being of different ages and having different language skills could become friends and get on well together ("In a short time we all became friends and that was quite surprising because we attended the courses of different faculties and we were not the same age.");

- regarding (intercultural) relationships: it was friendship with those placed in the same linguistic context that acted as a catalyst for their surpassing the difficulties in learning a foreign language ("Our friendship surpassed the difficulties of a foreign language.");

- $\quad$ regarding efforts at both cognitive and social level: ("We struggled hard to understand and help each other");

- regarding status: getting multilingual skills and multicultural experience and identifying similarities helped R not to feel alienated or isolated ("I felt close 
to the students from the eastern part of Europe, because we were all coming from the old communist block");

- regarding possibilities of language learning: ("Linguistically I discovered that the process of language learning in class ... differs from the concrete linguistic experiences in a foreign country.").

b) knowledge: about other cultures' values; specific traditions ("I got to know the world by tasting the traditional cuisine."); the way of living and making sense of life; political, linguistic and cultural similarities/ differences between countries; similarities or differences in mentalities.

c) attitudes: openness towards others; friendship; acceptance; respect for others.

d) skills: of interpreting and relating facts; of interacting with the others.

Although one experience may seem irrelevant to readers, used in teaching, either as intensive or extensive reading, the linguistic autobiography can help students find in it an illustrative case study and possibilities of extending reflective learning. It can also contribute to the development of awareness and knowledge, as well as to the formation of multicultural attitudes and skills. On another level of analysis, the example offered by the autobiography may easily call for reciprocity of disclosure (of perspectives, images, actions and feelings).

\section{CONCLUSION}

Linguistic autobiographies "report" the author's knowledge and (also) experience with learning about other cultures and with learning languages in general, and they also offer the reader the author's accounts of how he makes sense of all the experiences he passes through. Introspective and retrospective in nature, these first-person accounts are "learning trajectories", "records of remarkable social repositioning and linguistic accomplishment" (Todeva and Cenoz 2009:16), influenced by various contextual factors. They represent "a wide range of combinations of dialect languages from both similar and very different linguistic families, ...while offering insights into the ways one creates a more fluid and complex identity when positioned in various speech and learning communities." (Todeva \& (enoz 2009:17) At the same time, they are based on reflection, raising awareness, critical thinking and self-evaluation components that need to be developed in students. In other words, they become educative devices.

\section{REFERENCES}

Bruner, J. S. 1990. Acts of Meaning. Cambridge, MA: Harvard University Press.

Burnett, R. 1991. Accouts and Narratives. In B. Montgomery and S. Duck (eds.) Studying Interpersonal Interaction. New York: The Guilford Press, 121-141.

Carbaugh,D.2007. Cultural Discourse analysis: Communication Practicesand Intercultural Encounters. Journal of Intercultural Communication Research 36/3, 167-182. 
Dörnyei, Z. 2007. Research methods in applied linguistics: quantitative, qualitative and mixed methodologies. 0xford: 0xford University Press.

Johnson, R. B. and A. J. Onwuegbuzie. 2004. Mixed Methods Research: A Research Paradigm Whose Time Has Come. Educational Researcher 33/7, 14-26.

Pavlenko, A. 2007. Autobigraphic Narratives as Data in Applied Linguistics. Applied Linguistics 28/2, 163-188.

Polkinghorne, D. 1988. Narrative knowing and the human sciences. Albany: State University of New York Press.

Riessman, C. 1993. Narrative Analysis. Qualitative Research Methods Series 30. London/ New Delhi: Sage Publications.

Todeva, E. and J. Cenoz. 2009. The Multiple realities of Multilingialism: Personal Narratives and Researchers` Perspectives. Berlin/New York: Walter de Gruyter.

\section{SUMMARY}

\section{LINGUISTIC AUTOBIOGRAPHIES OR MAKING SENSE OF ONE'S LANGUAGE LEARNING EXPERIENCE. CASE STUDY}

The aim of this paper is to offer insights into one type of personal/autobiographic narrative as a special form of accounting, considered not only an object, but also a means/tool of research in education. The paper starts from the general idea that linguistic autobiographies constitute an important source of information about the experience second/foreign language learners pass through, as well as about the way in which they come to make sense of it. One case study constitutes the basis for our analysis, in an attempt of identifying the reasons for which languages are learned, acquired, (re)used in everyday life various settings or, on the contrary, abandoned. The analysis is followed by the presentation of some possible implications that the practice and study of linguistic autobiography may have in language teaching and in student education, in general.

KEYWORDS: account/personal narrative, linguistic autobiography, content, context, form.

(Original scientific paper received 31.01.2011;

revised 06.09.2011;

accepted 19.09.2011) 